\title{
COMMENT
}

\section{ANTICOMPETITIVE DATA DISSEMINATION IN THE MEDICAL PROFESSION: THE CONFLICT BETWEEN THE SHERMAN ACT AND THE FIRST AMENDMENT}

The antitrust prohibitions of the Sherman Act ${ }^{1}$ in many ways have a "unique relationship" 2 with the free speech guarantees of the first ainendinent. ${ }^{3}$ By protecting the free flow of information between buyers and sellers, ${ }^{4}$ the Sherman Act protects first amendment rights to disseminate and receive information. ${ }^{5}$ By defining competition as the goal of its prohibitions, ${ }^{6}$ the Sherman Act, like the first amendment,

THE FOLLOWING CITATION WILL BE USED IN THIS COMMENT:

Havighurst, Professional Restraints on Innovation in Health Care Financing, 1978 DukE L.J. 303, hereinafter cited as Havighurst.

1. I5 U.S.C. \$ 1-7 (1976). Section 1 of the Sherman Act provides: "Every contract, combination in the form of trust or otherwise, or conspiracy, in restraint of trade or commerce among the several States, . . . is hereby declared to be illegal." Id. $\S 1$. Interpreting the broad language of the Sherman Act as congressional permission to establish a federal common law against trade restraints, the Supreme Court has established, under section 1, prohibitions agaimst a variety of forms of anticompetitive agreements, including data dissemination, see, e.g., Aunerican Column \& Lumber Co. v. United States, 257 U.S. 377 (1921); and boycotts, see, e.g., Eastern States Retail Lumber Dealers' Ass'n v. United States, 234 U.S. 600 (1914). See notes 20-59 infra and accompanying text.

2. Martyn, Lawyer Advertising: The Unique Relationship Between First Amendment and Antitrust Protections, 23 WAYNE L. REv. 167, 167 (1976). For a general discussion of the proposition that the Sherman Act complements the first arnendment in protecting the free exchange of inforination, see also Canby \& Gellhorn, Physician Advertising: The First Amendment and the Sherman $A C t, 1978$ DUKE L.J. 543.

3. U.S. CoNST. amend. I: "Congress shall make no law . . a abridging the freedom of speech ...."

4. "The courts that have considered the issue construe commercial advertising prohibitions as unlawfuI restraints on trade under the Sherman Act." Martyn, supra note 2, at 173; see, e.g., United States v. Gasoline Retailers Ass'n, 285 F.2d 688 (7th Cir. 1961); Louisiana Petroleum Retail Dealers v. Texas Co., 148 F. Supp. 334 (W.D. La. 1956).

5. See note 4 supra and note 8 infra.

6. The Supreme Court has mamtamed that the Sherman Act prohibition of "restraints of trade," 15 U.S.C. $\& 1$ (1976), should be interpreted as essentially prohibiting restrictions on competition. See Standard Oil Co. v. United States, 221 U.S. 1, $56-57$ (1910):

[W] hile the primciples concerning contracts in restraint of trade, that is, voluntary restraint put by a person on his right to pursue his calling, hence only operating subjectively, came generally [in the United States] to be recognized in accordance with the 
implicitly recognizes the importance of the free exchange of facts and ideas. ${ }^{7}$ Indeed, both courts and federal agencies have turned to Sherman Act prohibitions to protect the freedom of speech. ${ }^{8}$

The Sherman Act and the first amendment do not, however, always act in conjunction to protect the free exchange of information. In American Column \& Lumber Co. v. United States ${ }^{9}$ the Supreme Court established that the Sherman Act may prohibit exchanges of information among competitors when those exchanges lead to anticompetitive behavior. Simce American Column \& Lumber the Court has developed this Sherman Act prohibition, disallowing many anticompetitive information exchanges. Despite the Court's general intolerance of such exchanges, one group of competitors-physicians-were for many years protected from strict Sherman Act scrutimy and had significant freedom to disseminate potentially anticompetitive information. This freedom from strict antitrust review, known as the "learned professions exemption," 10 largely exeinpted anticonpetitive practices of the learned professions. In recent years the Court has eroded and arguably eliminated this special exemption. It appears that physicians' dissemination of anticompetitive data should now be subject to strict antitrust review. ${ }^{11}$

The expansion of Sherman Act prohibitions to the dissemination of anticompetitive data by physicians raises significant first amendment concerns, because such communications are often mextricably tied to important moral or ethical issues. Although the Sherman Act would, in the absence of any special exenuption, indiscriminately prohibit such

English rule, it came moreover to pass that contracts or acts which it was considered had a monopolistic tendency, especially those which were thought to unduly diminish competition and hence to enhance prices ... came also in a generic sense to be spoken of and treated as they had been in England, as restricting the due course of trade, and therefore as being in restraint of trade.

7. An essential component of perfect competition is perfect information, which requires the free exchange of facts and ideas. See R. LIPSEY \& P. STEINER, Economics 269 (4th ed. 1975).

8. See United States v. Gasoline Retailers Ass'n, 285 F.2d 688 (7th Cir. 1961) (invalidating under the Sherman Act an agreement between a union and gasoline station operators to refram from advertising). See also In re Amway Corp., 93 F.T.C. 618, 729 (1979) (appeal pending) (invalidating under antitrust prohibitions a restraint on price advertising). The extent to which the prohibitions of the Sherman Act are interchangeable with the free speech guarantees of the first amendment was graphically demonstrated in Bates v. State Bar, 433 U.S. 350 (1977). In Bates the Supreme Court intimated that a restraint upon attorney advertising might violate the Sherman Act. Because the restraint had been imposed by the Supreme Court of Arizona, however, the Court held that it fell into the "state action" exemption of Parker v. Brown, 317 U.S. 341 (1943), which exempts state action from Sherman Act liability. 433 U.S. at 359-62. Undaunted, the Court invalidated the restraint by relying on the first amendment. Id. at 363-84. See also Martyn, supra note 2 , at 173 n.30.

9. 257 U.S. 377 (1921). For a more detailed discussion of American Column \& Lumber, see notes 15-22 infra and accompanying text.

I0. See notes 50-52 infra and accompanying text.

11. See notes 53-68 infra and accompanying text. 
communications whenever they violate the prohibition against anticompetitive data dissemination, the Court's recent extension of first amendment guarantees to commercial speech indicates that these coinmunications deserve substantial first amendment protection. The concurrent expansion of Sherman Act prohibitions to medical profession communications and of first amendment protection to commercial speech has thus created an uncomfortable tension between the Sherman Act and the first amendment.

This Comment discusses the early development of the antitrust prohibitions of data dissemmation, and the traditional ineans of reconciling the tension between the Sherman Act and the first amendinent. Focusing on the medical profession, the Comment reviews the dissemination of anticompetitive data by physicians and the demise of the learned professions exemption that once permitted them to engage freely in anticompetitive activity. The Comment concludes that although the erosion of the learned professions exemption suggests that anticompetitive data dissemmation by physicians should be subject to strict Sherman Act review, the Court's analysis in the commercial speech cases ${ }^{12}$ imdicates that the first amendment protects such data dissemination. This conflict between the Sherman Act and the first amendment may be resolved, however, by distmguishing between data dissemmation imtended to coordmate anticompetitive conduct and data dissemination imtended to contribute to "the market place of ideas."13 By giving first amendment protection to the latter type of data dissemination and subjectimg the former to strict antitrust review, the Sherman Act could disallow manifestly anticompetitive schenes ${ }^{14}$ while intruding only minimally on first amendment guarantees.

\section{Antitrust Prohibitions of Data Dissemination}

American Column \& Lumber Co. v. United States ${ }^{15}$ was the first Supreme Court case to hold that the Sherman Act prohibits anticompetitive data dissemination. The case concerned a trade association $\mathrm{m}$ the hardwood mdustry that required its members to exchange information about sales, prices, production, and other details of manufacturing and

12. See notes 87-108 infra and accompanying text.

13. Consolidated Edison Co. v. Public Serv. Comm'n, 100 S. Ct. 2326, 2333 (1980).

14. For a recent argument that even the regular exchange of price and production imformation deserves first amendment protection, see Maginness, The Exchange of Price Information as a Restraint of Trade: Reassessing Per Se Rules in Light of First Amendment Protection of Commercial Speech, 48 FordHAM L. Rev. 1005 (1980).

15. 257 U.S. 377 (1921). 
merchandising. ${ }^{16}$ Despite the assertion by the association that the purpose of the exchange was to "furnish information to enable each member to intelligently make prices and to intelligently govern his production," 17 the Court employed the "rule of reason"18 to examine the actual purpose and the anticompetitive effect of the agreement. The purpose and the effect, the Court found, were to keep "the supply low and the prices high." 19 Over dissents by Justices Holmes ${ }^{20}$ and Brandeis, ${ }^{21}$ the Court held that a trade association's exchange of information could constitute "a combination and conspiracy in restraint of interstate commerce" within section 1 of the Shernian Act. ${ }^{22}$ Such data dissemination was therefore illegal. The Court never considered the first amendment rights of the trade association.

16. Id. at 393-95. Compliance with the trade association's information exchange agreement was not completely voluntary. Representatives of the association regularly reviewed and audited the members' reports. Any member who failed to comply with the association's requirements was not permitted to receive the reports of others. A member who failed to report for twelve days im six months would be expelled from the association. - Id. at 395.

17. Id. at 392-93.

18. Under the Sherman Act there are two complementary tests for determining when a potentially anticompetitive scheme is unlawful: the "rule of reason" and the "per se" rule. The classic statement of the rule of reason, which requires an examination of the purpose and the effect of a potentially anticompetitive scheme, was given by Justice Brandeis in Chicago Bd. of Trade v. United States, 246 U.S. 231 (1918):

The true test of legahty is whether the restraint imposed is such as merely regulates and perhaps thereby promotcs competition or whether it is such as may suppress or even destroy competition. To determine that question the court must ordimarily consider the facts peculiar to the busimess to which the restraint is applied; its condition before and after the restraint was imposed; the nature of the restraint and its effect, actual or probable. The history of the restraint, the evil believed to exist, the reason for adopting the particular remedy, the purpose or end sought to be attained, are all relevant facts. This is not because a good imtention will save an otherwise objectionable regulation or the reverse; but because knowledge of intent may help the court to interpret facts and to predict consequences.

Id. at 238.

In contrast, the per se rule requires no examination of effect; it applies to "agreements whose nature and necessary effect are so plainly anticompetitive that no elaborate study of the industry is needed to establish their illegality - they are illegal per se.' "National Soc'y of Professional Eng'rs v. United States, 435 U.S. 679, 692 (1978).

19. 257 U.S. at 404.

20. Id. at 412 (Holmes, J., dissenting). In his brief dissent, Justice Holmes observed that it was "surprising in a country of free speech" that the Supreme Court would prohibit the dissemination of useful production information. Id. at 413. Rathcr than explicitly arguing that the first amendment protected the information exchange, however, Justice Holmes supported his argument simply by contending "that the Sherman Act did not set itself against knowledge." Id. at 412 .

21. Id. at 413 (Brandeis, J., dissenting). Like Justice Holmes, Justice Brandeis suggested that "there is nothing in the Sherman Law which should limit freedom of discussion, even among traders." Id. at 416. Justice Brandeis likewise did not explicitly discuss the first amendment, but defended the trade association's scheme because it tended "to promote all in competition which is desirable." Id. at 418.

22. Id. at 412 . 
Having prohibited the data dissemination in American Column \& Lumber, the Court subsequently disallowed numerous commercial information exchanges. In United States v. American Linseed Oil Co ${ }^{23}$ the Court held that the daily reporting of the "intimate details" of prices and sales by manufacturers and distributors of linseed oil violated the Sherman Act. ${ }^{24}$ Similarly, in Sugar Institute v. United States ${ }^{25}$ the Court disallowed an agreement among competing sugar refiners to exchange information concerning "prices, terms, and conditions."26 Probably the most far-reaching of the Court's prohibitions of data dissemination was the 1969 case of United States v. Container Corp. of America. ${ }^{27}$ In Container Corp. competing sellers of corrugated containers informally and irregularly exchanged information about the most recent prices charged or quoted to specific customers. Sellers lowered their prices to ineet the prices of their.competitors, with the overall effect of stabilizing prices, "though at a downward level."28 Despite the lack of convincing evidence demonstrating an unlawful purpose or anticompetitive effect, ${ }^{29}$ the Court found that the inferences were "ir-

23. 262 U.S. 371 (1923). American Linseed Oil involved an agreement aunong inanufacturers and distributors to "mail by special delivery to the [information exchange] bureau a complete report of its carload sales," including "quantity and kind, price, and terms," at the "close of each day's business." Id. at 383. The purpose of the agreement, the Court found, was to substitute "intelligent competition" for the free market competition previously existing in the industry. The Court granted an injunction against the information exchange. Id. at 388-90.

24. Id. at 390 .

25. 297 U.S. 553 (1936).

26. Id. at 577. Before Sugar Institute, in Maple Flooring Mfrs. Ass'n v. United States, 268 U.S. 563 (1925), the Court had seeined ready to retreat from the broad condemnations of American Column \& Lumber and American Linseed Oil. In Maple Flooring a trade association of flooring manufacturers exchanged information concerning inanufacturing costs, freight rates, salcs volume, and prices. The association also held inectings at which corporate representatives would "discuss the industry and excliange views as to its problems." Id. at 566-67. The Court did not disallow the association's activities, finding that the record was "barren of evidence" indicating the defendants' purpose was to discourage production or coinpetition, or to otherwise restrain commerce. Id. at 577. American Column \& Lumber and American Linseed Oil were distinguished on the grounds that the "peculiar circumstances" of each case had led to the conelusion that competition had been restrained. Id. at 584-85.

The Court's decision in Maple Flooring is open to criticism. The exchanges of information about manufacturing costs and freight rates did suggest an unlawful purpose by the members of the trade association. L. Sullivan, HANDBOOK OF THE LAW of ANTITRuST 269 (1977). Regardless of the correctness of the holding, however, subsequent cases have deinonstrated that Maple Flooring did not mark the beginning of a retreat froun strict judicial scrutiny of commercial data dissemination. Indeed, the current vitality of the Maple Flooring holding is questionable in light of the more recent data dissemination cases. See notes 27-38 infra and accompanying text.

27. 393 U.S. 333 (1969).

28. Id. at 336 .

29. See id. at 344 (Marshall, J., dissenting). Justice Marshall's dissent highlighted the absence of any convincing evidence demonstrating an unlawful purpose or anticompetitive effect, arguing that neither the anticompetitive purpose nor the anticoinpetitive effect necessary to estab- 
resistable that the exchange of price information [had] an anticompetitive effect in the industry." 30 Noting that interference with the selling price of a commodity is unlawful per se, ${ }^{31}$ the Court concluded that the information exchange violated the Sherman Act. ${ }^{32}$ As in American Column \& Lumber, the Court did not discuss first amendinent considerations.

Container Corp. has been correctly described as a confusing decision. ${ }^{33}$ The Court's willingness to declare an exchange of information unlawful in the virtual absence of any evidence of wrongful purpose or anticompetitive effect raised serious questions whether any exchange of price information is permissible. ${ }^{34}$ The Court's reference in the opinion to the per se rule further confused practitioners and legal scholars concerning whether price exchange agreements were unlawful per se or unlawful only under the purpose-and-effect analysis of the rule of reason. ${ }^{35}$ To some extent, the confusion surrounding Container Corp. was

lish a Sherman Act violation had been demonstrated. Discussing the Government's failure to demonstrate an anticompetitive effect, Justice Marshall referred to the district court's finding "that the corrugated contamer market was highly competitive and that each defendant engaged in active price competition." Id. at 345. Justice Marshall did not find the container market "suffciently oligopolistic" to justify the inference that an anticompetitive effect necessarily followed from an information cxchange. Id. at 343. Turning to whether the defendants manifested an unlawful purpose, Justice Marshall emphasized that "[t]he Court does not hold that the agreement in the present case was a deliberate attempt to stabilize prices. The evidence in the case, largely the result of stipulation, would not support such a liolding." Id. at 344 . In the absence of evidence demonstrating an unlawful purpose or anticompetitive effect, Justice Marshall concluded that the information exchange did not violate the Sherman Act. Id. at 347. See generally Note, Antitrust Implications of the Exchange of Price Information Among Competitors: The Contamer Corporation Case, 68 Mich. L. REv. 720, 729-30 (1970).

30. 393 U.S. at. 337.

31. See note 18 supra.

32. 393 U.S. at 338.

33. See generally Kefauver, The Legality of Dissemination of Market Data by Trade Associations: What Does Container Hold?, 57 CORNELl L. REv. 777 (1972); Monroe, Practical Antitrust Considerations for Trade Associations, 1969 UTAH L. REV. 622, 626 n.24; Comment, The Creation of a Separate Rule of Reason: Antitrust Liability for the Exchange of Price Information Among Competitors, 1979 Duke L.J. 1004, 1013-15; Note, supra note 29, at 730-31; Note, Antitrust Liability for an Exchange of Price Information-What Happened to Container Corporation?, 63 VA. L. REv. 639 (1977); Note, Guidelines for Data Dissemination Through Trade Associations, 10 WAsHBURN L.J. 93, 101-02 (1970).

34. See L. Sullivan, supra note 26, at 272: "[Container Corp.] leaves the law in doubt. If one projects from this case alone, then except for the most flagrantly competitive market showing no indications of concentration, it is hard to picture a market where an attorney would confidently predict that an exchange of price information is valid."

35. In a concurring opinion, Justice Fortas argued that the Court had not held that exchanges of price information were illegal per se. In his view, "the probability that the exchange of specific price information led to an unlawful effect upon prices" was "adequately buttressed by evidence in the record." 393 U.S. at 339 (Fortas, J., concurring). Justice Fortas's conclusion was precisely the opposite of that reached by Justice Marshall. Id. at 345 (Marshall, J., dissenting). See note 29 supra. 
resolved in United States v. United Gypsum Co. ${ }^{36}$ in which the Court explicitly endorsed the rule of reason while reversing the criminal convictions of gypsum board inanufacturers for exchanging price information. ${ }^{37}$ Nevertheless, Container Corp. indicates the Court's intolerance of anticompetitive exchanges of commercial information. ${ }^{38}$ Container Corp. also illustrates that even in the Court's inost sweeping prohibitions of commercial data dissemination, it has generally neglected the free speech guarantees of the first ainendinent.

\section{The Expansion of Antitrust Prohibitions: The Sherman ACt and the Medical Profession}

Like the trade association in American Column \& Lumber and the competing sellers in Container Corp., medical societies and less formally arranged groups of practicmg physicians also dissemmate various proposals, resolutions, and opinions on a variety of professional concerns. These intraprofessional communications-which may be termed "professional speech"39-can take a variety of forms and in some cases may greatly inhibit coinpetition in the health care industry. ${ }^{40}$ For exainple, a medical society inight circulate a proposal or opinion condemning a health insurer's adoption of a particular costcontainment practice. This circulation of the society's professional opinion, by educating members as to what best suits their economic

36. 438 U.S. 422 (1978). In United Gypsum members of the gypsum-board industry, including the four largest producers, exchanged price imformation by telephone. Despite the members' claim that the information exchange was necessary to comply with the Robimson-Patman Act, 15 U.S.C. $\S 13(b)$ (1976), which allows a seller to engage in price discrimination in order to meet the price of a competitor, the Supreme Court held that the price information exchange should be "subject to close scrutiny under the Sherman Act." 438 U.S. at 459 . For a detailed discussion of the significance of United Gypsum, see Comment, supra note 33, at 1037-39.

37. 438 U.S. at 441 . But see Comment, supra note 33, at 1035-37 (arguing that the Gypsum Court "in effect applied a per se test to price information exchanges," id. 1037). Although United Gypsum is distinguishable from Container Corp. on the ground that United Gypsum involved a criminal trial, the Supreme Court clearly mdicated that the rule of reason was the proper test to be applied in all data dissemmation cases, thus resolving some of the confusion resulting from Container Corp. The Court, in reaching this conclusion, cited Justice Fortas's concurring opinion in Container Corp. 438 U.S. at 441 n.16. See note 35 supra.

38. Although the principal cases prohibiting data dissemimation under the Sherman Act have concerned the exchange of price information, the exchange of other inarketing information having an anticompetitive effect can be prohibited as well. See, e.g., American Column \& Lumber Co. v. United States, 257 U.S. 377 (1921). "In general, the analytic approaches [employed in evaluating price circulation] are appropriate in evaluating circulation of non-price information . . . " $L$. Sullivan, supra note 26, at 274.

39. Purdue, The First Amendment Status of Professional Speech (April 17, 1978) (unpublished memorandum in the Duke University School of Law Library).

40. For a detailed discussion of physicians' restraints on competition in the health care industry through anticompetitive data dissemmation and other means, see Havighurst. 
self-interests, may lead individual physicians to refuse to deal with that insurer and thereby compromise cost-containment innovations in the health care industry. ${ }^{41}$ Or, more simply, physicians may adopt, circulate, and adhere to an advisory fee schedule even though the inedical society does not enforce it.

There are many examples of the dissemination of anticompetitive data by the medical profession. In Michigan a state medical society sent mailgrams to society members criticizing an innovative health insurance program and claiming that under the prograin physicians were "being asked to subsidize Blue Shield's cost containment efforts." 42 Similarly, the American Medical Association recently undertook a detailed study of a new prepaid health care plan and issued a report critical of the plan. ${ }^{43}$ In Indiana a cost-containment effort aroused the opposition of the Indiana State Medical Association, which formally adopted a resolution critical of the plan. ${ }^{44}$

Despite the anticompetitive nature of much of this professional speech, and despite the Supreme Court's manifest imtolerance of anticompetitive data dissemination, the Court had been hesitant to subject professional speech to the data dissennmation prohibitions of American Column \& Lumber and Container Corp. This hesitation has apparently resulted from the continued viability of the "learned professions exemption," which permitted the learned professions to engage in various types of anticompetitive activity while remaining generally isolated from Sherman Act liability. ${ }^{45}$ The Supreme Court's erosion and

41. Id. 354 .

42. New Blue Shield Policies Stir Protests from Michigan MDs, Am. Med. News, Sept. 19, 1977, at I, col. 2. In addition to circulating mailgrams critical of the innovative insurance program, the medical society called an emergency session of the society's House of Delegates "to consider the new actions." Id. col. 4.

43. See HMO Study Assesses Cost, Quality, Access to Care, Am. Med. News, Aug. 5, 1980, at 14 , col. 1 . Of the many concerns currently facing the medical profession, the use of HMOshealth maintenance organizations--has probably led to the most extensive disseınination of anticompetitive data. See, e.g., HMO Subsidies Come Under Fire, Am. Med. News, Aug. 5, 1980, at 1, col. 1. See generally Kissam, Health Maintenance Organizations and the Role of Antitrust Law, 1978 DUKe L.J. 487.

44. Indiana MDs Hit Blue Shield Benefit Plans, Am. Med. News, Nov. 14, 1977, at 19, col. 4. Although there is some evidence that medical societies are now attenpting to temper their anticompetitive data dissemination, see New Ethical Principles for Nation's Physicians Voted by AMA House, Am. Med. News, Aug. 5, 1980, at 1, col. 3, "other evidence suggests that medical organizations are still using their power to shape the economic environment in which physicians operate." Havighurst 316. See, e.g., HMO Subsidies Come Under Fire, supra note 43. Until recently the slogan "An Informed Membership Is Our Greatest Strength" appeared on the masthead of Ameri. can Medical News. See, e.g., Am. Med. News, Aug. 29, 1977, at 1.

45. Although the cases do not specify precisely which professions are "learned professions," they do indicate that this category includes at least accountants, architects, attorneys, clergymen, dentists, doctors, engineers, opticians, optometrists, pharmacists, and veterinarians. J. VON KaLI- 
arguable elimination of this special exemption now appears, however, to expose the learned professions to strict Sherman Act review.

The demise of the learned professions exemption is troublesome because of the moral, ethical, 46 or simply occupational problems that are the topic of professional speech. Subjectimg this speech to strict Sherman Act review would require that the speech be prohibited whenever it is motivated by anticompetitive intent, or has an anticompetitive effect. ${ }^{47}$ The expansion of first amendment guarantees to commercial speech, ${ }^{48}$ however, suggests that physicians' professional speech deserves first anendment protection. ${ }^{49}$ The tension between the free speech guarantees of the first amendment and the data dissemmation prohibitions of the Sherman Act promises to ripen imto a direct confrontation.

\section{A. The Erosion of the Learned Professions Exemption.}

The notion that the learned professions are exempt from Sherman Act scrutiny apparently originated with a simple assertion by Justice Holmes, in dictuin, that "a firm of lawyers sending out a member to argue a case . . . does not engage in such commerce" as would trigger Sherman Act scrutiny. ${ }^{50}$ Despite this inauspicious beginning the exemption prospered, inaking courts hesitate to impose Sherman Act sanctions on the learned professions. In United States $\nu$. Oregon State Medical Society, ${ }^{51}$ for exainple, the Supreme Court, holding that a

NOWSKI, ANTITRUST LaWs AND TRADE Regulation \$ 49.01[1] n.1 (1979). Of these professions, doctors have engaged most frequently in anticompetitive practices. See generally Havighurst.

46. See, e.g., C. Koop, The Right To Live; The Right To DIE (1979). In his book, which is apparently directed to the general public as well as to fellow physicians, Dr. Koop discusses several "emotional issues" currently facing the medical profession on moral and ethical grounds. Arguing against abortion, for example, Dr. Koop emphasizes the "essential horror of such acts," and he suggests that in Roe v. Wade, 410 U.S. 113 (1973), and Doe v. Bolton, 410 U.S. 179 (1973), the Supreme Court einbraced "the moral views of paganism." C. Koop, supra, at 39, 58. Dr. Koop is not hesitant to criticize fellow physicians for what he considers their failure to weigh moral concerns. In response to Chief Justice Burger's assertion in Roe that "the vast majority of physicians ... act only on the basis of carefully deliberated medical judgments relating to life and health," 410 U.S. at 208 (Burger, C.J., concurring), Dr. Koop remarks, "the Chief Justice does not know physicians as well as I do." C. Koop, supra, at 40-41. Like the trade association that circulated commercial information in American Column \& Lumber, see notes 15-22 supra and accompanying text, Dr. Koop, besides publishing his views, disseminated them through "discussions with inedical students, interns, and residents" and in "seminars on personal ethics." C. Koop, supra, at 13.

47. See note 18 supra.

48. See notes 76-108 infra and accompanying text.

49. See notes 109-30 infra and accompanying text.

50. Federal Baseball Club v. National League, 259 U.S. 200, 209 (1922). See Martyn, supra note 2 , at 183 n. 89 .

51. 343 U.S. 326 (1952). 
medical society had not violated the Sherman Act, stated:

[T] here are ethical considerations where the historic direct relationship between patient and physician is involved which are quite different than the usual considerations prevailing in ordinary commercial matters. This Court has recognized that forms of competition usual in the business world inay be demoralizing to the ethical standards of a profession..$^{52}$

Although for many years the Supreme Court seemed willing to recognize that the learned professions were "quite different" 33 from other groups of competitors, the Court significantly conipromised the learned professions exemption in the landmark case of Goldfarb v. Virginia State Bar. ${ }^{54}$ Goldfarb involved a minimum fee schedule for lawyers that the Fairfax County Bar Association published and the Virginia State Bar enforced. The Court of Appeals for the Fourth Circuit held, in light of the learned professions exemption, that the Virginia State Bar was not subject to antitrust scrutiny,ss but the Supreme Court reversed. Stating that "[t]he nature of an occupation, standing alone, does not provide sanctuary from the Sherman Act,"s6 the Court held that the lawyers' price-fixing was illegal.57

Goldfarb limited, but did not eliminate, the learned professions exemption. In a footnote, the Goldfarb Court suggested that it "would be unrealistic to view the practice of professions as interchangeable with other business activities." 58 The Court declined to discuss further the special treatment accorded the learned professions under the antitrust laws, but after Goldfarb the learned professions continued to enjoy isolation from strict Sherman Act scrutimy. ${ }^{59}$

52. Id. at 336. For a detailed critical analysis of the Oregon State opinion, see Goldberg \& Greenberg, The Effect of Physician-Controlled Health Insurance: U.S. v. Oregon State Medical Society, 2 J. Health Pol., Pol'y \& L. 48 (1977).

53. 343 U.S. at 336.

54. 421 U.S. 773 (1975).

55. Goldfarb v. Virginia State Bar, 497 F.2d 1, 13-15, 20 (4th Cir. 1974), rev'd, 421 U.S. 773 (1975).

56. 421 U.S. at 787.

57. Id. at $792-93$.

58. Id. at 788 n.17. The Court did not specify the degree to which the learned professions remained exempt. The Court inerely stated:

The fact that a restraint operates upon a profession as distinguished from a business is, of course, relevant in determining whether that particular restraint violates the Sherman Act. It would be unrealistic to view the practice of professions as interchangeable with other business activities, and automatically to apply to the professions antitrust concepts which originated in other areas. The public service aspect, and other features of the professions, inay require that a particular practice, which could properly be viewed as a violation of the Sherman Act in another context, be treated differently. We intimate Id. no view on any other situation than the one with which we are confronted today.

59. Boddicker v. American State Dental Ass'n, 549 F.2d 626 (9th Cir. 1977), cert. denied, 434 U.S. 825 (1978), probably best reveals the special antitrust review accorded the learned professions 


\section{B. National Society of Professional Engineers v. United States.}

Despite the Goldfarb Court's apparent willingness to recognize the continued validity of the learned professions exemption, the most recent Supreme Court case to raise the issue has significantly limited, if not eliminated, the exenuption. National Society of Professional Engineers $v$. United States ${ }^{60}$ dealt with a professional engineering society's canon of ethics that prohibited the society's inembers from submitting competitive bids for engmeering services. If a chent insisted on receiving a competitive bid, the canon required the engmeer to withdraw from the proposed job. ${ }^{61}$ The society argued that the ethical restraint should be upheld agamst a Sherunan Act challenge because its goal was to serve the public. Competitive bidding, the society maintained,

both before and after Goldfarb. In Boddicker a group of dentists claimed that a state dental association had violated the Shernan Act by requiring membership im the national dental association as a condition of membership. Failure to retain membership in the national dental association resulted in expulsion from the local organization and the loss of the "substantial benefits" of membership, including group insurance, participation in education programs, and the referral of patients by other members. 549 F.2d at 628 . The plaintiff argued that the national dental association, unlike the local association, offered no significant benefits. Id. at 628-29. Although under other circumstances the membership requirement would probably have been declared a per se violation of the Sherman Act, see United States v. Loew's, Inc, 371 U.S. 38 (1962); Northern Pac. Ry. v. United States, 356 U.S. 1 (1958); International Salt Co. v. United States, 332 U.S. 392 (1947), the court of appeals held that the dental association would escape liabihity if it could prove that the purpose of the requirement was not to restrain trade, but to "serve the public." 549 F.2d at 632 . The court concluded that permitting a learned profession to survive a Sherman Act challenge if its action contributed "directly to improving service to the public" allowed "a harmonization of the ends that both the professions and the Sherman Act serve." Id.

The rationale of Boddicker suggests that the Sherman Act does not always prohibit the learned professions as guardians of public welfare from estabhishing rules to assure "a high order of professional excellence." Id. at 628 . The anticompetitiveness of the rules therefore had to be balanced against the benefits that accrued to the public. Id. at 632 . By employing such a balancing test, the Boddicker court not only substituted the rule of reason for the per se rule, but also departed fron the principle that competition is the goal of the Sherman Act. See United States v. Topco Assocs., 405 U.S. 596 (1972); Umited States v. Sealy, Inc., 388 U.S. 350 (1967); Timkin Roller Bearing Co. v. United States, 341 U.S. 593 (1951). But see Appalachian Coals, Inc. v. United States, 288 U.S. 344 (1933). Nevertheless, the Supreine Court denied certiorari. 434 U.S. 825 (1978).

60. 435 U.S. 679 (1978).

61. The soniewhat complex ethical rules of the engimeering society essentially prevented any competition from interfering with the rates charged by individual engmeers. The sections in issue provided:

The Engineer will not compete unfairly with another engineer by attempting to obtain employment or advancement of professional engagements by coinpetitive bidding . . . .

c. He shall not solicit or submit engineering proposals on the basis of competitive bidding. Competitive bidding for professional engineering services is defined as the formal or informal submission, or receipt, of verbal or written estimates or cost or proposals in terms of dollars ... or any other measure of coinpensation whereby the prospective chent may compare engineering services on a price basis prior to the time that one engineer. . . has been selected for negotiations.

Id. at 683 n.3. 
would lead to deceptively low bids and thereby tempt engineers to do inferior work "with consequent risk to public safety and healtll."62

The Supreme Court rejected the society's argument. Because Congress had decided by enacting the Sherman Act that competition would best serve the public, 63 the society could not impose its views of "the costs and benefits of competition on the entire marketplace."64 The Court's analysis strictly conformed to traditional Sherman Act analysis, which has consistently defined competition as the Act's goal and has recognized that restraimts on competition are therefore unlawful. ${ }^{65}$ The Court noted the footnote in Goldfarb that had suggested that professional services differed from other busmess services, ${ }^{66}$ but maintamed that the footnote meant that ethical rules of a professional society could serve only to "regulate and promote . . . competition," not to inhibit it. ${ }^{67}$ By suggesting that ethical rules may only regulate and promote competition, the Court all but eliminated the learned professions exemption. Any trade agreement that promotes competition is lawful under the Sherman Act. Requiring the learned professions to conform to this standard merely subjects them to traditional Sherman Act review. ${ }^{68}$

Professional Engineers is significant also because it constitutes the first explicit skirmisl in the Supreme Court between the Sherman Act and the free speech rights of professionals. The district court's order to remedy the society's unlawful restraint of trade had prohibited the society from "adopting any official opimion, policy statement, or guideline stating or implying" that competitive bidding was unethical. ${ }^{69}$ This order, the society contended, abridged its first amendment rights. The Court rejected this contention. ${ }^{70}$ Significantly, however, the Court did

62. Id. at 693 .

63. Id. at $694-95$.

64. Id.

65. See United States v. Topco Assocs., 405 U.S. 596 (1972); United States v. Sealy, Inc., 388 U.S. 350 (1967); Timkin Roller Bearing Co. v. United States, 341 U.S. 593 (1951). But see Appalachian Coals, Inc. v. United States, 288 U.S. 344 (1933).

66. See note 58 supra.

67. 435 U.S. at 696.

68. Because the trade restriction imposed by the Society of Professional Engineers dealt with price, the Court might not impose the rigorous holding of Professional Engineers on other anticompetitive agreements by professional societies. The Court has usually been more anxious to prohibit price restramts than other restramts on competition. See, e.g., United States v. SoconyVacuum Oil Co., 310 U.S. 150 (1940). Although nothing in the Professional Engineers opinion suggests that a different standard should apply to nonprice restraints, some courts have continued to recognize a limited exemption for professional trade restraints that do not deal with price. See, e.g., Bogus v. American Speech \& Hearing Ass'n, 582 F.2d 277, 291 n.18 (3d Cir. 1978).

69. 435 U.S. at 697.

70. Id. 
not decide that the society enjoyed no first amendment protection; imstead, the Court stated that the district court, having found the society guilty of a Sherman Act violation, was einpowered to fashion appropriate restraints even though those restraints inight curtail hberties that the society "might otherwise enjoy."" Wh While alluding to a potential conflict between the Sherman Act and the first aunendment, the Court in Professional Engineers avoided that conflict by restricting the society's freedoin of speech "under the cloak of remedial judicial action."72 The Court left unresolved the doctrimal conflict between the first amendment and the Sherman Act.

\section{The Expansion of First Amendment Guarantees: The Freedom of SPEech ANd the Medical Profession}

With the demise of the learned professions exemption, physicians can expect to be subject to increasingly strict Sherman Act review. Indeed, several commentators have suggested that the data dissemination prohibitions of American Column \& Lumber and Container Corp. should apply to physicians' professional speech. ${ }^{73}$ And the Supreine Court in Goldfarb intimated im dictuin that these data dissemination prohibitions may apply to the learned professions. ${ }^{74}$ It appears inevitable, then, that the freedom to communicate once accorded physicians

71. Id.

72. 435 U.S. at 701 (Burger, C.J., dissenting). Although Chief Justice Burger was apparently not prepared to undertake a detailed defense of the engineers' first amendment rights, he did register his disapproval with the Court's conclusion. He stated: "The First Amendment guarantees the right to express [standards of ethics] and that right cannot be impaired under the cloak of remedial judicial action." Id.

73. See, e.g., Havighurst 358-59. Discussimg the increasing level of Sherman Act scrutimy of physicians, Professor Havighurst suggests:

In [American Column \& Lumber] the Supreme Court found unlawful an exchange of information and opinion where such information and opmion was employed to knit a multitude of competitors into a conspiracy. The somewhat coinparable activities of pro. fessional organizations should be subject to similar scrutiny, and, if a profession's pro. pensity for concerted action appears particularly great, a commensurately strict limitation on intraprofessional communications would be justified.

Id. See also Kissam, supra note 43, at 511; Comment, supra note 33, at 1019:

Recent decisions of the Supreme Court have looked behind the protective veil of the learned professions exemption and have imposed Sherman Act hability upon professional organizations. This trend would seem to indicate that price information exchanges involving professional associations should be analyzed under the extended rule of reason employed in Container Corp.

74. The Goldfarb Court, addressing "a naked agreement" to fix attorneys' fees, 421 U.S. at 782, indicated in dictum that eveu if the attorneys had merely disseminated pertiment fee information they would have been subject to the American Column \& Lumber data dissemination prohibition. Distinguishing an agreement to fix prices from the mere dissemination of price information, the Court stated, "A purely advisory fee schedule issued to provide guidelines, or an exchange of price information without a showing of an actual restraint ou trade, would present us with a different question, e.g., American Column Co. v. United States . . ." 421 U.S. at 781. See also 
will not be permitted to continue. ${ }^{75}$

The doctrinal conflict between the first amendment and the Sherman Act has not resulted exclusively from the demise of the learned professions exemption, however. In recent years the Supreme Court has extended first amendment protection to commercial speech. ${ }^{76} \mathrm{Al}-$ though the professional speech of physicians does not involve the advertisement of goods or services, and therefore may not qualify as commercial speech as the Court has used that term, ${ }^{77}$ the rationale behind the commercial speech cases suggests that professional speech deserves significant first amendment protection. ${ }^{78}$ The Court's expansion of first amendment protection to commercial speech has thus operated to increase the tension between the Sherman Act and the first amendment.

\section{A. Commercial Speech and the First Amendment.}

In 1942 the Supreme Court decided in Valentine v. Chrestensen ${ }^{79}$ that the first amendment did not protect commercial speech. In Chrestensen the owner of a submarine distributed handbills in the New York streets advertising the submarine and soliciting visitors. To circumvent a New York ordinance prohibiting the distribution of commercial advertisements, ${ }^{80}$ he printed on the back of the handbill a protest of the city's refusal to provide wharfing facilities. The police prevented the submarine owner from distributing the handbill. In upholding New York's ordinance, the Court considered both the city's right to regulate the use of its streets ${ }^{81}$ and the submarme owner's first

Arizona v. Maricopa County Medical Soc'y, [1980-1] TRADE CAS. (CCH) If 63,239, at 78,155 (9th Cir. 1980).

75. See Havighurst 359.

76. See generally Bayus, The Constitutional Status of Commercial Expression, 3 HastingS Const. L.Q. 761 (1976); Meiklejohn, Commercial Speech and the First Amendment, 13 CALIF. W.L. REv. 430 (1977); Rotunda, The Commerical Speech Doctrine in the Supreme Court, 1976 U. ItL. L.F. 1080; Comment, Commercial Speech and the First Amendment: An Emerging Doctrine, 5 HOFSTRA L. REv. 655 (1977).

77. Commercial speech, roughly defined, is "speech of any form that advertises a product or service for profit or for business purpose." J. NowAK, R. ROTUNDA, \& J. Young, HANDBOOK ON Constitutional Law 767 (1978).

78. See notes 109-30 infra and accompanying text.

79. 316 U.S. 52 (1942).

80. Id. at 53. The ordinance stated in part: "No person shall throw, cast or distribute, or cause or permit to be thrown, cast or distributed, any handbill, circular, card, booklet, placard or other advertising matter whatsoever, in or upon any street or puble place . . ." Id. at 53 n.1.

81. The Court stated that although streets are proper places for the dissemination of public information, a city may prevent "what it deems an undesirable invasion of, or interference with, the full and free use of the highways by the people . . . ." Id. at 54-55. 
ainendinent rights. ${ }^{82}$ Finding, however, that the submarine owner's actual purpose was to advertise his submarine rather than to make a political protest about the unavailability of wharfing facilities, the Court concluded that the owner was engaging in purely commerical speech. ${ }^{83}$ The Constitution, the Court decided, imposes "no . . . restraint on government as respects purely commercial advertising." 84 Given the owner's commercial purpose, the public's interest in receiving the information was not an issue in the Court's determination. ${ }^{85}$

It is not coinpletely clear whether, under the commercial speech doctrime of Chrestensen, physicians' professional speech would be accorded first ainendment protection. Because such speech involves primarily professional or otherwise commercial matters, a Chrestensentype analysis might preclude first ainendment protection. Whether Chrestensen would in fact isolate professional specch from first amendment protection, however, is of hittle significance today. Although Chrestensen has not been explicitly overruled, later Court decisions have seriously undermined the vahdity of its holding. ${ }^{86}$ Under these later decisions, professional speech now should receive significant first amendinent protection.

Virginia State Board of Pharmacy v. Virginia Citizens Consumer Council, Inc., ${ }^{87}$ decided twenty-four years after Chrestensen, marks the Court's most significant departure fron the Chrestensen commercial speech doctrine. Virginia State Board involved a Virginia statute that prohibited pharmacists from publishing, advertising, or otherwise promoting any price or credit terms of prescription drugs. ${ }^{88}$ The Court

82. Id.

83. Id. at 55 .

84. Id. at 54 .

85. Id. at 55. The lower court had recognized implicitly that isolating commercial speech from first amendment guarantees would lead to the prohibition of important communication that was of interest to the public, because of the difficulty of categorizing speech as "commercial." Chrestensen v. Valentine, 122 F.2d 511, 515-16 (2d Cir. 1941), rev'd, 316 U.S. 52 (1942).

86. See Central Hudson Gas \& Elec. Corp. v. Public Serv. Comm'n, 100 S. Ct. 2343 (1980); In re Primus, 436 U.S. 412 (1978); Bates v. State Bar, 433 U.S. 350 (1977); Carey v. Population Servs. Int'1, 431 U.S. 678 (1977); Linmark Assocs. v. Township of Willingboro, 431 U.S. 85 (1977); Virginia State Bd. of Pliarmacy v. Virginia Citizens Consumer Council, Inc., 425 U.S. 748 (1976); Bigelow v. Virginia, $42 I$ U.S. 809 (1975); New York Times Co. v. Sullivan, 376 U.S. 254 (1964); Joseph Burstyn, Inc. v. Wilson, 343 U.S. 495 (1952); Murdock v. Pennsylvania, 319 U.S. 105 (1943). But see Friedman v. Rogers, 440 U.S. 1 (1979).

87. 425 U.S. 748 (1976).

88. The statute provided that a plarmacist licensed in Virginia was guilty of unprofessional conduct if he advertised, "in any manner whatsoever, any amount, price, fee, premium, discount, rebate or credit terms . . . for any drugs which may be dispensed only by prescription." Id. at 749-50. 
found that the intent of the pharmacists in promoting the drugs, like that of the subinarine owner in Chrestensen, was purely commercial:

Our pharmacist does not wish to editorialize on any subject, cultural, philosophical, or political. He does not wish to report any particularly newsworthy fact, or to make generalized observations even about commercial matters. The "idea" he wishes to communicate is simply this: "I will sell you the X prescription drug at the Y price."89

Although under Chrestensen such a commercial intent would have precluded first amendment protection, ${ }^{90}$ the Virginia State Board Court held that "commerical speech, like other varieties, is protected" by the first amendment. ${ }^{91}$ The Court held the Virginia statute unconstitutional. 92

What distinguishes the Court's analysis in Virginia State Board from its analysis in Chrestensen is that the Chrestensen Court considered only the interest of the speaker in disseminating commercial information. Because the first amendment was directed primarily to noncommercial speech, the Court concluded that the speaker's commercial intent could preclude first ainendment protection. ${ }^{93}$ In Virginia State Board, however, the Court considered not only the "purely economic" interest of the speaker, ${ }^{94}$ but also the commercial and noncommercial interests of the recipients and of society as a whole. ${ }^{95}$ The Court noted that the recipients of the advertisements, whose welfare depended on the procurement of prescription drugs, mamtamed an especially "keen" interest "in the free flow of commercial information."96 Generalizing, the Court stated that "[e]ven an individual advertiseinent, though entirely 'commercial,' inay be of general public inter-

89. Id. at 761 .

90. See notes 83-85 supra and accompanying text.

91. 425 U.S. at 770.

92. Id.

93. See notes 83-85 supra and accompanying text.

94. 425 U.S. at 762.

95. Id. at 763-65. The determination of the degree of first amendment protection that a specific type of speech receives is essentially a two-step process. First, the interests of the speaker, the audience, and society must be weighed against the costs of permitting the speech in question to be protected. Second, assuming the balancing test favors first amendment protection, the Court must determine the permissible scope of regulation of the protected speech. This is the analysis the Court employed in Virginia State Board, in which the Court assessed the interests of the advertiser, id. at 762, the consumer, id. at 763-64, and society, id. at 764, and weighed these interests against the justifications for the advertising ban, id. at 766-68.

The Court used an identical analysis in Bates v. State Bar, 433 U.S. 350 (1977), holding that the Supreme Court of Arizona's restraint upon attorney advertising violated the first amendment. Id. at 363-65, 368-79. After concluding that the justifications for the advertising ban did not outweigh the interests in free speech, the Court, as it had in Virginia State Board, outlined some permissible regulations. Id. at 383-84.

96. 425 U.S. at 763. 
est."97 The justification for the Virginia statute, "[a]rrayed against these substantial individual and societal interests," could not withstand first ainendinent scrutiny. ${ }^{98}$

Since Virginia State Board the Supreine Court has repeatedly reaffirmed that commerical speech is entitled to first annendment protection. In Linmark Associates v. Township of Willingboro ${ }^{99}$ the Court, relying on Virginia State Board, held that the first amendment protected the display of home "for sale" and "sold" signs. ${ }^{100}$ Similarly, in Carey v. Population Services International, ${ }^{101}$ the Court invalidated a state law that prohibited anyone, includimg licensed pharmacists, from advertising or displaying contraceptives. ${ }^{102}$ In Bates v. State Bar ${ }^{103}$ the Court refused to allow a state supreme court to mamtam rules prohibiting attorneys froin advertising. ${ }^{104}$ And, more recently, im In re Primus ${ }^{105}$ the Court overturned a state supreme court's holdimg that an American Civil Liberties Union attorney had violated a state disciplinary rule "by attempting to sohicit a client."106 These decisions indicate that the "casual, almost offhand"107 holding of Chrestensen is no longer authoritative. Commercial speech can no longer be regulated without regard to the first amendment implications of the regulation. ${ }^{108}$

\section{B. Professional Speech and the First Amendment.}

Professional speech deserves as much, or more, first amendinent protection than commerical speech. Professional speech embodies more than the advertisement of goods and services; it involves the communication, annong professionals, of ethical, moral, and occupational concerns. ${ }^{109}$ At the heart of professional speech is the communication of value judgments about the status and future of the profession. The concerns frequently raised in professional speech certainly lie closer to the core of first amendment protection than the purely commercial con-

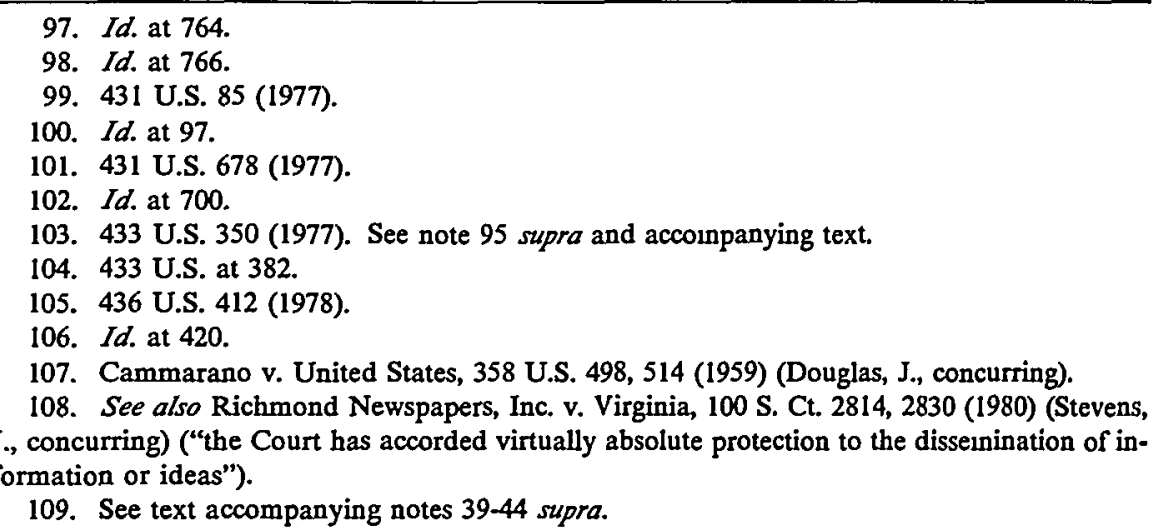


cerns raised in the commercial speech cases. ${ }^{110}$ Indeed, permitting professional speech a higher level of protection than pure commercial speech is consistent with the Court's traditional protection of the right to disseminate and receive information pertinent to moral and ideological considerations. ${ }^{111}$ Moreover, professional speech should not lose first amendment protection merely because economic considerations motivate it. The Supreme Court has held that such motives are not sufficient to remove otherwise ideological speech from the parameters of first amendment protection. ${ }^{112}$

A separate assessment of the imterests affected by professional speech also suggests that it deserves sigmificant first amendment protection. Virginia State Board and subsequent cases have identified three such interests: the speaker's interest in disseminating information, the listener's interest in receiving information, and the interest of society in free cominumication among individuals. ${ }^{113}$ Because professional speech deals with both the occupational and ideological concerns of the inedical profession, physicians, who constitute both the disseminators and the recipients of professional speech, have a strong imterest in its free exchange. Similarly, society benefits from the free exchange of ideas and health care innovations that contribute to the development of the health care industry. The protection of professional speech thus ensures uninhibited contributions to the "market place of ideas." 114

Nevertheless, the Supreine Court has indicated that it initially determines whether a form of speech is entitled to first anendment protection by balancing the first amendment rights of those affected by the speech against the disadvantages of extending first amendment guarantees. ${ }^{115}$ The interests of the speaker, the histener, and society must therefore be weighed against the costs of protecting professional

110. Though commercial speech may concern items of general pubhic concern, see, e.g., Bigelow v. Virginia, 421 U.S. 809,822 (1975), its primary characteristic is that it motivated by a desire to advertise some product or service in order to reap a profit.

111. Justice Stewart emphasized in Virginio State Board the distinction between ideological speech and mere commercial speech. He suggested that ideological speech is entitled to a higher degree of first amendment protection because, unlike commercial speech, it is "integrally related to the exposition of thought-thought that may shape our concepts of the whole universe of inan." 425 U.S. at 779 (Stewart, J., concurring).

112. See Joseph Burstyn, Inc. v. Wilson, 343 U.S. 495, 501-02 (1952) ("That books, newspapers, and magazines are published and sold for profit does not prevent them from being a form of expression whose hberty is safeguarded by the First Amendment"). See also Smith v. California, 361 U.S. 147, 150 (1959); Murdock v. Pennsylvania, 319 U.S. 105 (1943).

113. 425 U.S. at 762-65; see Bates v. State Bar, 433 U.S. 350, 363-65 (1977). See also Linmark Assocs. v. Township of Willingboro, 431 U.S. 85, 96 (1977); Bigelow v. Virginia, 421 U.S. 809, 822 (1975).

114. Consolidated Edison Co. v. Pubhic Serv. Comm'n, 100 S. Ct. 2326, 2333 (1980).

115. See notes $94-98$ supra and accompanying text. 
speech. There is, of course, a significant disadvantage, not relevant in the commercial speech cases, to extending first amendment protection to professional speech: the danger of permitting physicians to engage in uninhibited anticompetitive communication. ${ }^{116}$ Under the rule of reason, the Sherman Act prohibits communication that is likely to have an anticompetitive effect. ${ }^{117}$ Extending first amendment protection to professional speech would necessarily limit traditional Sherman Act prohibitions, and permit physicians, either intentionally or unintentionally, to engage in anticompetitive activity. ${ }^{118}$

The dilemma presented by this conflict between the Sherman Act and the first amendnent is aggravated by the Court's persistent refusal to permit speech restrictions based on the speech's "primary effect"the effect of the speech when those who receive the information act upon it. ${ }^{119}$ Under the Sherman Act's rule of reason, courts prohibiting commercial data dissemmation do so because of its effect when competitors receiving the information act upon it. ${ }^{120}$ In determining whether professional speech deserves first amendment protection, the possibility that the communication violates the rule of reason may therefore be an improper consideration. Arguably, the government's reasons for prohibiting anticonipetitive data dissemmation should outweigh the first amendment concerns involved. Nevertheless, the Supreme Court has refused to permit speech's primary effect to preclude first amendment protection even when faced with important state objectives.

For example, in Linmark Associates v. Township of Willingboro ${ }^{121}$ a township passed an ordinance prohibiting the posting of "for sale" and "sold" signs that was imtended to discourage panic selling by white homeowners who feared an influx of blacks into the township. The Court held the ordmance unconstitutional, statimg, "Willingboro has proscribed particular types of signs based on their content because it fears their "primary' effect-that they will cause those receiving the information to act upon it."122 That the township enacted the ordinance to achieve the important objective of promoting stable, racially inte-

116. Because commercial speech promotes rather than inhibits competition, the protection of commercial speech does not present this problem.

117. See note 18 supra.

118. See notes 39-44 supra and accompanying text.

119. See Limmark Assocs. v. Township of Willingboro, 431 U.S. 85 (1979).

120. See note 18 supra and accompanying text.

121. 431 U.S. 85 (1977). See generally Note, Commercial Speech, Blockbusting, and the First Amendment: Limmark Associates, Inc. v. Township of Willingboro, 7 CAP. L. Rev. 271 (1977); 23 LOY. L. REv. 1038 (1977); 46 U. CIN. L. REv. 883 (1977).

122. 431 U.S. at 94. 
grated housing was not decisive. ${ }^{123}$ "[T] the State from achieving its goal by restricting the free flow of truthful information."124

Virginia State Board ${ }^{125}$ is another example of the Court's refusing to permit speech restrictions based on the speech's primary effect. In holding that the first amendment protects prescription drug advertising, the Court reviewed the arguments of pharmacists that such advertising could unfavorably influence professional standards. ${ }^{126}$ As im Linmark Associates, however, the Court recognized that the alleged influence on professional standards was not the direct result of the advertising; rather, the pharmacists feared that professional standards would be hurt because those receiving the information would act upon it. ${ }^{127}$ In essence, then, the pharmacists wanted to prohibit drug advertising because they feared the advertising's primary effect. ${ }^{128}$ Prohibitimg speech because of anticipated reactions to it is, the Court held, not permissible: "It is precisely this kind of choice, between the dangers of suppressing information, and the dangers of its misuse if it is freely available, that the First Amendment inakes for us." 129

The rule of reason, which defines Sherman Act prohibitions according to the effect of allegedly anticompetitive activity, thus runs into direct conflict with the mandates of Linmark Associates and Virginia State Board. Although distinctions can certainly be drawn between commercial speech and professional speech, the fundamental primciple of these commercial speech cases is applicable to both: the state may not control the lawful conduct of its citizens by keeping them im ignorance. ${ }^{130}$ In a balancing of first amendment guarantees against anti-

123. Id. at 94-95. Although the Court emphasized that it "recognized that substantial benefits fiow to both whites and blacks from interracial association," id., the strong state interest could not preclude first amendment protection. Id. at 95.

124. Id. at 95.

125. Virginia State Bd. of Pharmacy v. Virginia Citizens Consumer Council, Inc., 425 U.S. 748 (1976). See notes 87-92 supra.

126. 425 U.S. at 766-70. The pharmacists argued that the aggressive price competition that would result from unlimited drug advertising would force pharmacists to cut costs by reducing professional standards and services. Id. at 767-68.

127. Id. at 769.

128. The Court stated: "The advertising ban does not directly affect professional standards one way or the other. It affects them only through the reactions it is assumed people will have to the free flow of drug information." Id.

129. Id. at 770 .

130. Despite the Supreme Court's unequivocal tone in Virginia State Board and Linmark Associates, a recent decision intimates that in narrow cases a state may restrain speech because of its primary effect. In Central Hudson Gas \& Elec. Corp. v. Public Serv. Comm'n, 100 S. Ct. 2343 (1980), the Court imvalidated a state's restraint on advertismg that promoted the use of electricity. Id. at 2353-54. Significantly, however, the Court intimated that under narrow circumstances such a restraint might be permissible, given the important state goal of conserving energy. Id. at 2353; 
trust prohibitions, the balance therefore shifts substantially in favor of first amendment protection. Prohibiting speech, even to serve an important state objective such as preserving competition, cannot withstand first amendment scrutiny when the prohibition is intended to prevent the speech's primary effect. Professional speech, even though potentially anticompetitive, should therefore be protected by the first amendment.

\section{The Reconciliation of Sherman Act Prohibitions and FIRST AMENDMENT GUARANTEES}

That professional speech is entitled to significant first anjendment protection does not inean, however, that the state can never restrict it. The Supreme Court has consistently indicated, in cases extending first amendment protection to new forms of speech, that protection does not suggest that the speech "n1ay never be regulated in any way."131 To be valid, the regulations must be reasonable and closely tied to the harm they are designed to prevent, with minimal intrusion on free speech guarantees. ${ }^{132}$

\section{A. The Traditional Reconciliation of the Sherman Act and the First Amendment: The Noerr-Pennington Doctrine.}

The Supreine Court has faced the task of reconciling Sherman Act prohibitions and first ainendment guarantees in another context. To protect the first amendinent right to petition, the Court developed the Noerr-Pennington doctrime ${ }^{133}$ for those instances in which the exercise of that right constitutes anticoinpetitive activity that, in the absence of

see id. at 2355 (Blackmun, J., concurring). In a concurring opinion, Justice Blackmun vehemently argued that permitting such a restraint would depart froin the rule of Virginia State Board and Linmark Associates that "the State 'may not [pursue its goals] by keeping the public in ignorance.'" Id. at 2356 (quoting Virginia State Board, 425 U.S. at 770) (einphasis added by Justice Blackmun). Even if the case should signal a departure froin Virginia State Board and Linmark Associates, it is doubtful that the Court would extend this departure to forms of speech other than the narrow "promotional" advertising, i.e., advertising merely intended to stimulate consumption, see $100 \mathrm{~S}$. Ct. at 2347 (majority opinion), involved in that case. See id. at 2350 ("The First Amendment's concern for commercial speech is based on the informational function of advertising").

131. Bates v. State Bar, 433 U.S. 350, 383 (1977).

132. See Central Hudson Gas \& Elec. Corp. v. Public Serv. Comm'n, 100 S. Ct. 2343, 2350-51 (1980). See also L. Tribe, American Constirutional Law 576-84 (1978).

133. See generally Fischel, Antitrust Liability for Attempts to Influence Government Action: The Basis and Limils of the Noerr-Pennington Doctrine, 45 U. CHI. L. REv. 80 (1977); Holzer, An Analysis for Reconciling the Antitrust Laws with the Right to Petition: Noerr-Peumington in Light of Cantor v. Detroit Edison, 27 EMORY L.J. 673, 678-83 (1978). See also Havighurst 360; Note, Physician Infuence: Applying Noerr-Pennington to the Medical Profession, 1978 DUKE L.J. 701, $701-05$. 
constitutional protection, would violate the Sherman Act. The NoerrPennington doctrine thus is a logical starting place in the search for a regulatory scheine to reconcile the Sherman Act and the freedoin of speech. ${ }^{134}$ An exammation of the doctrine reveals, however, that although it helps reconcile conflicts between the Sherman Act and the first amendment right to petition, it is not helpful in reconciling conflicts between the Sherinan Act and the freedom of speech.

The first case to pose the Sherinan Act against the first amendment right to petition, Eastern Railroad Presidents Conference v. Noerr Motor Freight, Inc., ${ }^{135}$ involved a competitive battle between the railroads and the trucking industry for long-distance freight hauling. The railroads had hired a public relations firm to conduct a publicity campaign against the truckers, designed, the Court stated, to "foster the adoption and retention of laws ... destructive of the trucking business," and to "create an atmosphere of distaste for the truckers annong the general public."136 The truckers' complaint alleged that the railroads, in their attempt to influence the legislature by ineans of a publicity canpaign, had violated the Sherman Act. ${ }^{137}$

Writing for the Court, Justice Black admitted that the railroads' intent had been to discourage competition. ${ }^{138}$ Even though such a purpose would have been sufficient to make the activity unlawful under the rule of reason, ${ }^{139}$ the Court held that the railroads' actions escaped Sherman Act hability because "inere attempts to influence the passage or enforcement of laws" could not constitute a violation of the Act. ${ }^{140}$ Construing the Act to forbid the railroads' actions, the Court explained, would raise "important constitutional questions" because the Act, by inhibiting the right of the people to inform the government of their wishes, would regulate not only "business activity" but "political activity" as well. ${ }^{141}$ Such a legislative intent, the Court held, cannot be im-

134. See Havighurst 355-60.

135. 365 U.S. 127 (1961).

136. Id. at 129 .

137. Id. at 130-31. The complaint described the railroads" campaign as "vicious, corrupt, and fraudulent," first because "the sole nnotivation behind it was the desire on the part of the railroads to injure the truckers and eventually to destroy them as competitors," and second because the railroads had used "the so-called third party technique, that is, the publicity matter was made to appear as spontaneously expressed views of independent persons and civic groups when, in fact, it was . . paid for by the railroads." Id. at 129-30.

138. Id. at 138.

139. Under the rule of reason either an anticompetitive purpose or an anticompetitive effect violates the Sherman Act. See note 18 supra.

140. 365 U.S. at 135.

141. Id. at $137-38$. 
ferred from the Sherman Act. ${ }^{142}$

The Court reiterated the holding of Noerr in United Mine Workers v. Pennington, ${ }^{143}$ the second case to match the first amendment against the Sherman Act. In Pennington the Umited Mine Workers and several large coal companies agreed to urge the Secretary of Labor to enact regulations concerning purchases in the coal spot market and wages. The Court found that the purpose of the agreement was to gain control of the coal market by driving sinall companies out of business. ${ }^{144}$ As in Noerr, such a purpose under a traditional rule-of-reason analysis would have led the Court to hold the agreement unlawful. ${ }^{145}$ But, as im Noerr, instead of holding the agreement unlawful the Court held that the right to petition" 146 "shields from the Sherman Act a concerted effort to influence publie officials regardless of intent or purpose."147 Under Noerr and Pennington the Court would not construe the Sherman Act to violate first amendment guarantees.

The Noerr-Pennington solution for reconciling first amendment guarantees with Sherman Act prohibitions is at best a solution of limited applicability. The Noerr-Pennington doctrine assumes that speech can be classified as either political or business-related. ${ }^{148}$ The Sherman Act regulates busmess activity, the Noerr Court presumed, and the first amendment protects political activity. ${ }^{149}$ Because the right to petition constitutes "not business activity, but pohitical activity,"150 it falls under the protection of the first amendinent and does not trigger the Sherman Act.

This analysis is consistent with the Court's antitrust treatment of commercial data dissemination in earlier cases. As business activity, the data dissemmation apparently fell under the prohibitions of the

142. Id. The Court was adamant in its refusal to permit the Sherman Act to inhibit the exercise of political freedoms. The Court stated that "the whole concept of representation depends upon the ability of people to make their wishes known to their representatives." Id. at 137. A finding that the Sherman Act could prevent individuals from freely informing the government thus would impute to the Act "a purpose which would have no basis whatever in the legislative history of the Act." Id.

143. 381 U.S. 657 (1965).

144. Id. at 660 .

145. See note 18 supra.

146. Although Pennington failed to mention the right to petition exphicitly, its reliance on $\mathrm{No}$. err indicated that "the rationale for exempting attempts to induce govermental action from the antitrust laws was closely related to important first amendment policies." Holzer, supra note 133, at 680 .

147. 381 U.S. at 670.

148. Eastern R.R. President's Conference v. Noerr, 365 U.S. at 137.

149. Id. at 138 .

150. Id. at 137 . 
Sherman Act without triggering first amendment protections. ${ }^{151}$ The Noerr-Pennington doctrine's rehance on the distimction between business and political speech, however, renders the doctrine ineffective for resolving the inodern conflict between the Sherman Act and the first ainendment. The erosion of the Chrestensen commercial speech doctrine has made it infeasible to categorize speech as either busmess or political for the purpose of determining the applicability of first amendment guarantees. ${ }^{152}$

\section{B. Other Traditional Regulatory Schemes.}

The Supreine Court in the past decade has outlined a variety of other permissible scheines besides Noerr-Pennington to regulate the freedoin of speech. Commercial speech that is "false, deceptive, or misleading" is subject to special restrictions. ${ }^{153}$ This regulation does not apply to professional speech, however, which is most frequently concerned with ideas, because "there is no such thing as a false idea." 154 Nor can regulations of data dissemination be characterized as "time, place, or inanner" restrictions. ${ }^{155}$ The goal of antidissemmation regulations is not to restrict a troublesome ineans of communication, but to prevent the intraprofessional communication because of its content. ${ }^{156}$ The other regulations the Court frequently einploys are similarly unhelpful: professional speech does not concern transactions that "are themselves illegal," 157 need not employ the electronic broadcast

151. See notes $15-38$ supra and accompanying text.

152. See notes 86-98 supra and accompanying text.

153. See Bates v. State Bar, 433 U.S. 350, 383 (1977).

154. Virginia State Bd. of Pharmacy v. Virginia Citizens Consumer Council, Inc., 425 U.S. 748, 780 (1976) (Stewart, J., concurring) (quoting Gertz v. Robert Welch, Inc., 418 U.S. 323, 339 (1974)).

155. See Martin v. Struthers, 319 U.S. 141 (1943).

156. See, e.g., National Soc'y of Professional Eng'rs v. United States, 435 U.S. 679 (1978).

157. Virginia State Bd. of Pharmacy v. Virginia Citizens Consumer Council, Inc., 425 U.S. 748, 772 (citing Pittsburgh Press Co. v. Pittsburgh Comm'n on Human Relations, 413 U.S. 376 (1973)). In Pittsburgh Press the Supreme Court upheld against a first amendment challenge an ordinance that prohibited newspapers from carrying "help wanted" advertisements in sex-designated columns. Noting the illegality of sex discrimination, the Court analogized the sex-designated advertisements to advertisements "proposing a sale of narcotics or soliciting prostitutes." Id. at 388 . The first amendment, the Court concluded, did not prevent the government from prohibiting speech that proposed such illegal transactions. Id.

The regulation delineated in Pittsburgh Press, however, is inapphicable to the Sherman Act prohibition of data dissemination. The dissemination of commercial or ethical information does not propose transactions that are necessarily illegal; nor can the disseminated information, as in Pittsburgh Press, be used only to accomplish illegal ends. Instead, the dissemination of commercial or ethical information siniply constitutes speech that can, in particular circumstances, be put to illegal use. If the first amendment left unprotected all speech that could possibly be used illegally, it would protect very little. 
media, ${ }^{158}$ and is not obscene. ${ }^{159}$

The "clear and present danger" test of Brandenburg v. Ohio 160 may seem to be a useful means of regulating professional speech. Under that test the state may prohibit speech that is "directed to inciting or producing imminent lawless action and is likely to produce such action." 161 Because both the Brandenburg test and the rule of reason consider the purpose and the effect of the speech, ${ }^{162}$ the Brandenburg test seems to be an attractive compleinent to the rule of reason. Unfortunately, however, using the Brandenburg test in the antitrust context would cause a serious problem. Under the rule of reason, an unlawful intent, even in the absence of an actual showing of anticoinpetitive effect, is sufficient to find an activity unlawful. ${ }^{163}$ By requiring that the furst amendment protect anticompetitive speech unless the speech is "likely to produce" an anticompetitive effect, the Brandenburg test, unlike the rule of reason, would require an examination of the anticipated effect of the allegedly anticompetitive speech in every case. Such a requirement would be unfortunate, because determining anticompetitive effect in antitrust suits can be a lengthy, detailed, and expensive undertaking. ${ }^{164}$ Anticipating anticompetitive effect would be equally diffcult. Subjectimg courts to this burdensome analysis would significantly lengthen antitrust hitigation and conipromise the effectiveness of the Sherman Act. ${ }^{165}$

158. See Red Lion Broadcasting Co. v. FCC, 395 U.S. 367 (1969).

159. See Roth v. United States, 354 U.S. 476 (1957).

160. 395 U.S. 444 (1969). Brandenburg reversed on first amendment grounds the conviction of a Ku Klux Klan leader who had been charged with advocating political reform through violence.

161. 395 U.S. at 447. The Brandenburg test was discussed in the commercial speech context in Carey v. Population Servs. Int'l, 431 U.S. 678 (1977). Carey involved the applicability of first amendment guarantees to a New York statute that prohibited the advertising or display of contraceptives. In defense of the statute, the state argued that the advertisements would be "offensive and embarrassing" and would "legitimize sexual activity of young people." Id. at 701. The Court rejected these assertions. The possibility that speech can be offensive is not a sufficient justification for suppressing that speech; nor does the remote possibility of illicit sexual behavior justify constraints on advertising contraceptives. Citing Brandenburg, the Court stated that in the absence of obscenity the only permissible test was whether the advertisements were "directed to inciting imminent lawless action and . . . likely to incite or produce such action." Id.

162. See note 18 supra.

163. See note 18 supra.

164. See J. Von Kalinowski, supra note $45, \S 6.02[4]$.

165. In light of the difficulty of conclusively determining anticompetitive effect in antitrust cases, courts applying the Brandenburg test to professional speech might well slip imto the habit of merely inferring anticompotitive effect from the manner and content of the physicians' data dissemination. See United States v. Container Corp. of America, 393 U.S. 333 (1969). See also notes 27-35 supro and accompanying text. Such a test would amount to little more than applying a per se rule to professional speech, and would compromise to an unfortunate degree the ability of plyysicians to communicate. 
The traditional regulatory schemes employed by the Supreme Court are therefore unhelpful in devising a regulatory scheme to reconcile the conflict between the Sherman Act and the first amendment. The Supreme Court, however, has faced opposition between economic regulation and the first anendment in another context: labor picketing. Although picketing is regarded as "speech plus"166 and is therefore traditionally accorded only limited first amendment protection, ${ }^{167}$ a review of the Court's decisions involving the conflict between the right to picket and state law suggests a regulatory scheme that is uniquely suited for regulating anticompetitive data dissemination. ${ }^{168}$

\section{Labor Picketing and the First Amendment.}

In both the labor-picketing and data-dissemination situations, the desire to protect the free exchange of facts and ideas through intellectual persuasion conflicts with the desire to leave economically disruptive or otherwise undesirable behavior unprotected. The Court's labor picketing cases have largely fallen into disuse with the federal preemption of the labor law field; 169 the picketing cases are nonetheless useful in the first ainendinent-Sherman Act conflict. A careful review of the Court's picketing decisions not only highlights the difficulties in reconciling economic regulation with first ainendment guarantees, but also suggests a scheme for reconciling the opposing pohcies embodied in each.

In Thornhill v. Alabama ${ }^{170}$ the Supreme Court established that labor picketing is entitled to first amendment protection. A picketing laborer was arrested for violating an Alabama statute that prohibited any person froin loitering near a business to deter other persons from dealing with it. The Court carefully noted that the laborer's protest had been peaceful, and that his purpose had been to advise customers of the business's poor labor practices. "The freedom of speech," the Court stated, "einbraces at least the liberty to discuss publicly and truthfully all inatters of public concern . . . ."171 Though a inore narrowly writ-

166. Brandenburg v. Ohio, 395 U.S. at 455 (Douglas, J., concurring).

167. See L. TR1BE, supra note 132, at 598-99.

168. See Purdue, supra note 39 , at 5.

169. See Comment, Political Boycott Activity and the First Amendment, 91 Harv. L. Rev. 659, 663 (1978). For a discussion of federal preemption of the labor law area, see Cox, Federalism in the Law of Labor Relations, 67 HaRv. L. REv. 1297 (1954).

170. 310 U.S. 88 (1940).

171. Id. at 101. By highlighting the role of public concern, the Thornhill Court emplasized a consideration that was ignored less than two years later in Chrestensen, and that eventually led to the decline of the Chrestensen commercial speech doctrine. See notes 86-98 supra and accompanying text. 
ten regulation of labor picketing might have been permissible, ${ }^{172}$ a blanket prohibition was not. The Court held the Alabama statute unconstitutional on its face. ${ }^{173}$

Despite the breadth of the Thornhill holding, the Court later significantly restricted the right to picket. The case most clearly inarking the Court's retreat, Giboney v. Empire Storage \& Ice Co., ${ }^{174}$ involved picketing by union meinbers of a company that transacted business with nonunion workers. ${ }^{175}$ The sole purpose of the picketmg was to force the nonunion workers to jom the umon. ${ }^{176}$ The trial and appellate courts had enjoined the umon's picketing under a local trade statute; the Supreine Court affirmed. In contrast to its holding in Thornhill, the Giboney Court suggested that the state's power to regulate trade should be parainount, and that nothing in the first amendment suggests otherwise. ${ }^{177}$ The Court vaguely distinguished Thornhill as being directed against sweeping state prohibitions and therefore inapplicable to the facts of Giboney. ${ }^{178}$

The holding in Giboney is difficult to harmonize with the Thornhill mandate that states "dealing with the evils arising from industrial disputes . . . [may not] impair the effective exercise of the right to discuss freely industrial relations . . . ."179 Less than two years after Giboney, however, Archibald Cox recommended a means for reconciling Thornhill and Giboney. ${ }^{180}$ Cox asserted that the cases involved two different forms of picketing. In Giboney the picketing had been directed not toward gaining the sympathy of disinterested third parties, but toward

172. 310 U.S. at 104-05.

173. Id.

174. 336 U.S. 490 (1949).

175. In Giboney members of the Ice and Coal Drivers Umion in Kansas City attempted to induce nonmember drivers to jom the union. When most of the nonunion drivers refused, the union members set out to obtain agreements from the city wholesale ice distributors that they would not sell ice to nonunion drivers. Agreements were obtained from every distributor except Empire Storage and Ice. After warning Empire, the union picketed its place of business. Id. at 492.

176. $I d$.

177. Id. at 504. The Court's language was unequivocal: "We hold that the state's power to govern in this field is parainount, and that nothing in the Constitutional guarant[e]es of speech or press compels a state to apply or not to apply its antitrade restraint law to groups of workers, businesses, or others." Id.

178. Id. at 499-500:

[Thornhill] was directed toward a sweeping state prohibition which this Court found to embrace "nearly every practicable, effective ineans whereby those interested-including the employees directly affected-may enlighten the public on the nature and causes of a labor dispute." . . . [T]he general statement of the limitation of a state's power to impair free speech was not intended to apply to the fact situation presented here . . . . (quoting Thornhill v. Alabaina, 310 U.S. 88, 104 (1940)).

179. 310 U.S. at 104.

180. Cox, Strikes, Picketing and the Constitution, 4 VAND. L. Rev. 574 (1951). 
coercing competing workers into a certain type of desirable conduct. Cox termed this "signal" picketing because of its signal to nonunion members that they should jom the union. ${ }^{181}$ In Thornhill, on the other hand, the picketing had been intended to educate and persuade disinterested third parties in hopes of soliciting their willing sympathy and support. Cox terms this activity "publicity" picketing. ${ }^{182}$ The two types of picketing are subtly distinguishable. Publicity picketing imvolves the dissemination of information in the hope of obtaining willing support through imtellectual persuasion; signal picketing does not imvolve information dissemination with an eye toward persuasion, but merely operates to coerce or coordinate a desired response.

The Suprene Court did not explicitly adopt Cox's distinction between publicity and signal speech in later cases dealing with state prohibitions of picketing. Professor Cox's distinction is nevertheless consistent with the Court's analysis in these cases, which recognizes that speech intended only to convey information should be accorded greater first aniendment protection than speech imtended to do other than convey information. ${ }^{183}$ Although Cox's test may no longer be useful for reconciling the tension between the right to picket and state law, it is useful for reconciling the inodern tension between the first amendment and the Sherman Act in the context of physicians' professional speech. Under the Cox test, the first amendment would not protect physicians' dissemination of anticompetitive speech that was intended not to convey information, but to signal the desirability of some anticompetitive objective. The Sherman Act thus could constitutionally prohibit the dissemination. Where physicians genuinely intend to disseminate information or ideas, however, the first amendment would protect the professional data dissemination. Under the Cox test, for example, the circulation of an advisory fee schedule, presumably an effort to coordinate anticompetitive activity, would be prohibited under

181. Id. 593-95.

182. Id.

183. See International Bhd. of Teamsters Local 695 v. Vogt, Inc., 354 U.S. 284 (1957). In Vogt the Court upheld an injunction prohibiting laborers from picketing a business when their intent was to coerce the owner into pressuring his employees to join the union. Id. at 285. Although the Court did not explicitly rely on Cox's distinction between publicity and signal speech, it did admit that picketing is generally susceptible to regulation because it "involve[s] more than just communication of ideas . . ." Id. at 289. Further emphasizing the distinction between speech merely involving communication and speech involving "more than 'publicity," "id. at 290, the Court recalled that the picketers in Giboney had been "doing more than exercising a right of free speech or press." They had exercised "their economic power together with that of their allies to coinpel Einpire to abide by union rather than by state regulation of trade." Id. at 292 (quoting Giboney v. Empire Storage \& Ice Co., 336 U.S. 490, 509 (1949)). See also National Labor Relations Act, 29 U.S.C. § 158(b)(7) (1976). 
the Sherman Act's data dissemination prohibition. Such speech, contributing hittle or nothing to the marketplace of ideas, would be a classic case of signal speech. In contrast, an intraprofessional communication earnestly asserting that a certain health financing inechamism disrupts the doctor-patient relationship would enjoy first amendment protection as publicity speech-assuming that it was intended to persuade fellow physicians, rather than to signal a boycott. This does not mean, of course, that publicity speech may never be prohibited under the Sherman Act. Presumably, upon determining that a particular communication constitutes publicity rather than signal speech, a court would then balance the physicians' first amendment interest in its dissemmation against the significance of the threatened anticompetitive harm to determine whether or not to prohibit the dissemmation. In this way, the courts would accord maximuin protection both to competition in the health care industry and to competition in the physicians' marketplace of ideas. ${ }^{184}$

Applying the-Cox test to anticompetitive data dissemmation results in a practical and intellectually satisfactory means of reconciling the tension between the first amendment and the Sherman Act. The test is practical because, unlike the Noerr-Pennington doctrime, it does not rely on the problematic distinction between political activity and business activity. ${ }^{185}$ Moreover, in contrast to the clear-and-presentdanger test of Brandenburg, ${ }^{186}$ the Cox test does not require a finding of anticonipetitive effect before the speech can be prohibited. The Cox test thus moves in comfortable conformity with the rule of reason, which does not require an actual showing of anticompetitive effect once an anticonipetitive intent has been established. ${ }^{187}$

The Cox test is intellectually satisfactory because it does not restrict or inhibit legitimate atteinpts to dissemmate imformation. If the speaker's intent is to persuade, then significant first amendment protection applies to the data dissemination. Only where the speaker imtends to coerce or otherwise signal anticompetitive activity does first amendinent protection not apply. Intuitively, a speaker's dissemmation of data that is not intended to persuade intellectually, but rather is intended to coordinate illegal activity, should not receive first amend-

184. This analysis is consistent with the Supreme Court's recent decision in Central Hudson Gas \& Elec. Corp. v. Public Serv. Comm'n, 100 S. Ct. 2343 (1980), see note 130 supra, which intimated that "pronnotional" advertising-advertising intended only to promote consumptionmay be more subject to regulation than "informational" advertising-advertising intended to convey information beyond what is directly related to sales. See id. at $2347-48$.

185. See text accompanying notes 148-52 supra.

186. See notes 160-65 supra and accompanying text.

187. See note 18 supra. 
ment protection: such speech contributes nothing to the marketplace of ideas. ${ }^{188}$ The Cox test, unlike the more traditional regulations of speech, thus offers an attractive means for reconciling the tension between the Sherman Act and the first amendment.

\section{CONCLUSION}

The recent demise of the learned professions exemption suggests that intraprofessional communication by physicians will now be subject to the Sherman Act's prohibition of anticompetitive data dissemination. The Supreme Court's extension of first amendment guarantees to commercial speech, however, indicates that such data dissemination should be protected by the first amendment. The resulting tension may be resolved by distinguishing between signal speech, intended to signal or coordmate anticompetitive activity, and publicity speech, intended to persuade. Protecting publicity speecli under the first amendment, and prohibiting signal speech under the Sherman Act, would preserve earnest contributions to the marketplace of ideas while disallowing manifestly anticompetitive schemes.

Althougl the conflict between the Sherman Act and the first amendment arises most conspicuously in the traditionally anticompetitive medical profession, an identical dilemma exists in other professions. With the demise of the learned professions exemption, engineers, architects, pharmacists, and other professionals have been exposed to more strict Sherman Act review; their intraprofessional data dissemination nonetheless deserves first amendment protection. The Cox test, then, lias applicability beyond data dissemination by physicians and is an attractive means for reconciling the conflict between the Sherman Act and the freedoin of speech in these other professions. Despite the broad applicability of the Cox test, lowever, the test would not imvolve a significant departure from the traditional data dissemmation prohibitions exemplified by American Column \& Lumber. The regular exchange of price and production information, contributing little to the marketplace of ideas, would almost always constitute signal speecl, deserving no first amendment protection. Even a broad application of the Cox test would leave intact the Sherman Act's ability to disallow typical forms of anticompetitive data dissemination.

Michael R. Young

188. Cf. Central Hudson Gas \& Elec. Corp. v. Public Serv. Comm'n, 100 S. Ct. 2343, 2350 (1980) ("The First Amendment's concern for commercial speech is based on the informational function of advertising" rather than on its promotional function). 